\title{
A simulation study for optimizing the use of dairy bulls in breeding programs
}

\author{
J. JUGA, J. SYVÄJÄRVI, V. VILVA
}

Dept. of Animal Breeding, Agricultural Research Centre

SF-31600 Jokioinen, FINLAND

Finnish Animal Breeding Association P.O. Box 40

SF-01301 Vantaa, FINLAND

Dept. of Animal Breeding, The University of Helsinki

SF-00710 Helsinki, FINLAND

\begin{abstract}
Different breeding program alternatives in dairy cattle population were studied by simulation. Traits studied were milk production and a low heritability trait that is negatively correlated with milk production, e.g. fertility. The variable factors in the study were the number of young bulls to be tested, the number of daughters per bull in progeny testing, the number of tested bulls to be used and the weights for selected traits in an overall index of the bull's breeding value.

The influence of variable factors on genetic response in milk production and fertility was studied by calculating the average of real genotypic values on both traits for all cows born in the same year and having a complete first lactation record. This was done for a 25 year period. The population structure used in simulation was like the Finnish milk recorded Ayrshire population in which there are ca. 250000 cows.

The genetic response in milk production was improved by increasing the selection intensity amongst bulls. The negative effect of selection for milk yield on fertility could be decreased by giving the fertility a larger indexed weight. If the milk production had a weight of 1 and genetic correlation between traits was -0.20 then increasing the weight of fertility from 0.1 to 0.3 did not affect significantly the response in milk production.
\end{abstract}

Key words: Breeding program, Progeny testing

\section{Introduction}

From the genetic response in milk production reached in dairy cow population approximately $70-75 \%$ is due to selection of AI-bulls.
The transmittance of genetic superiority from bulls to cows is dependent on the use of tested and young bulls in the population. According to current breeding policy in Finland the best $30 \%$ of cows are recommended to be insemi- 
nated with a tested bull's semen, $60 \%$ of cows with a young bull's semen and the poorest $10 \%$ of cows with semen from beef bulls.

The number of young bulls that can be tested depends on the testing capacity and on the efficiency of the use of testing capacity. The number of bulls to be tested is limited by the amount of semen available and the size of the testing station. In spite of these fixed factors the breeding program can be improved by optimizing the selection intensity of tested bulls, the number of daughters in progeny test and the ratio of inseminations made with young and tested bulls.

Several studies of the influence of various factors on the genetic response in milk yield have been made concurrently with A.I. programmes (e.g. RENDEL and ROBERTSON 1950, Robertson and Rendel 1950, SKJERvold 1963, SKJeRvold and LANGHOLZ 1964 and VAN Vleck 1964). LindSTRöm (1969) has studied the predicted and realised genetic response in the Finnish dairy population. As a summary of the above mentioned studies he concluded that in large populations the genetic response depends rather more on the number of bulls to be tested than on the number of daughters per bull in progeny test, i.e. on the accuracy of the test. With an optimum use of AI, ideally an annual response of $2.0-2.5 \%$ could be reached in large populations $\left(\mathrm{V}_{\mathrm{AN}}\right.$ VLECK 1981), but in practise only $1.0 \%$ or less has been achieved. Some of the main reasons for this reduction are simultaneous selection on several traits, low selection intensity among tested bulls and low accuracy in evaluating of bull dams (VAN VLECK 1981).

In addition to maximizing the genetic response of milk production VAN VLECK (1964) and LINDHÉ (1968) considered also the net returns of A.I. mating plans. According to LINDHÉ (1968) the programme that maximizes the genetic response is usually not best if the maximum net return is considered, but the maximum net return is usually reached before the maximum genetic response. The economical optimization of A.I. breeding programs led into more sophisticated discounting procedures
(McClintock \& Cunningham 1974, and Hill 1974), in which the flow of selected genes is followed through different paths against time. The discounted return of an improvement that has been produced in breeding program, can be predicted by these methods. The method of McClintock and Cunningham (1974) has been used by LiNDSTRÖM and VILVA (1976) in optimizing the proportion of tested, young and beef bulls in the Finnish milk and meat breeding programme.

In 1984 there were 642000 dairy cows in Finland of which 307920 were milk recorded. 247587 of milk recorded cows were Ayrshire cows, 51460 were Friesian and 4640 were Finn cattle. Ca. 370 bulls can be tested annually in testing station out of 500 bull calfs born from bull dams. There has been a slight decrease in the number of bulls to be tested and an increase in the number of daughters per bull in progeny test, so that on average there have been 180 daughters per bull.

To find out the optimum number of progeny tested bulls and young bulls for the breeding program with relatively constant resources, a simulation study was carried out. In a simulation study the annual genetic response can be presented as the real genetic mean of animals born in different years. The simulation method is very flexible in studying the effects of different changes in the breeding programme. By using a simulation method the effect of random drift on genetic response can be estimated from the standard error of the mean over replicates.

\section{Simulation}

In the simulation study the population structure was designed to match with the Finnish milk recorded Ayrshire population. The fixed factors used in the study are given in Table 1. The factors varied in the study were the number of daughters per bull in progeny testing, i.e. the number of young bulls tested annually and the number of tested bulls to be used in the breeding program. The number of bull sires and the proportion of cows to be in- 
Table 1. The constants in the simulation study.

- population size

- replacement proportion $25 \%$ or

- proportions of bulls used for inseminations:

$60 \%$ with young bulls

$34 \%$ with tested bulls

$6 \%$ with beef bulls

\section{0,000 dairy cows}

63,000 Ist lact./year
- inseminations required:

(a)

1.7 inseminations/pregnancy

tested bulls: $\quad 3.6$ inseminations/lactation record

( $37 \%$ of 1st lactation records were made by daughters of young bulls,

$63 \%$ of 1st lactation records were made by daughters of tested bulls)

- 6 bull sires/year

- tested bulls were used for 3 years

- generation interval in sire to son path was 8 years

- heritabilities: milk production 0.25

fertility $\quad 0.05$ seminated with tested bull semen or with young bull semen were fixed (Table 1). The effect of these variable factors on the genetic response in milk production was studied by running different simulation alternatives with 20 replications of each. Animals were selected simultaneously on milk production and on a trait with a low heritability and with a negative genetic correlation $(-0.20)$ with milk production, e.g. fertility. Although for the main objective in selection, milk yield had a weight of 1 and fertility a weight of 0.1 , some alternatives were run by giving more weight to fertility. The different alternatives studied are given in Table 2. Population means were presented for both traits so that the improvement on milk production and the change in fertility could be followed.

The expected genetic responses in milk production were calculated from (RENDEL and ROBERTSON 1950)

$$
\mathrm{R}=\frac{\Delta \mathrm{G}_{\mathrm{SS}}+\Delta \mathrm{G}_{\mathrm{SD}}+\Delta \mathrm{G}_{\mathrm{DS}}+\Delta \mathrm{G}_{\mathrm{DD}}}{\mathrm{L}_{\mathrm{SS}}+\mathrm{L}_{\mathrm{SD}}+\mathrm{L}_{\mathrm{DS}}+\mathrm{L}_{\mathrm{DD}}},
$$

where $\Delta \mathrm{G}_{\mathrm{ij}}$ is the genetic change in different paths (designation: $\mathrm{SS}=$ for sire to son, $\mathrm{SD}=$ from sire to daughter, DS = from dam to son, and DD from dam to daughter) of gene transmission and $\mathrm{L}_{\mathrm{ij}}$ is the generation interval in the respective path. The expected responses are given in Table 3. The correlated responses in SS and SD paths, in which selection was practised on milk and fertility, were calculated from (FALCONER 1981)

$\mathrm{C} \Delta \mathrm{G}_{1}=\frac{\mathrm{i}}{\sigma_{1}} * \operatorname{cov}_{(\mathrm{a}) 11}$,

where $\mathrm{i}$ is the selection intensity, $\sigma_{1}$ is the standard deviation of the index and $\operatorname{cov}_{(\mathrm{a}) 11}$ is the additive genetic covariance of milk production with the index.

\section{Model}

Only the information of males was stored for the future use in the simulation. The genotypic values for bull dams were generated and chosen so that the mean over four lactations was above the selection criterion. Dams were randomly sampled because it was assumed that sires and dams are not related. The additive genetic value of a young bull (j) for trait $\mathrm{i}\left(\mathrm{a}_{\mathrm{ij}}\right)$ was generated from his sire's and dam's additive genetic values $\left(\mathrm{a}_{\mathrm{Si}}\right.$ and $\mathrm{a}_{\mathrm{Di}}$ respectively) as

$\mathrm{a}_{\mathrm{ij}}=0.5\left(\mathrm{a}_{\mathrm{Si}}+\mathrm{a}_{\mathrm{Di}}\right)+\mathrm{m}_{\mathrm{ij}}$,

where $m_{i j}$ is due to Mendelian sampling about the mean $0.5\left(\mathrm{a}_{\mathrm{Si}}+\mathrm{a}_{\mathrm{Di}}\right)$. 
Table 2. The variable factors used in simulation alternatives.

\begin{tabular}{lccc}
\hline & $\begin{array}{c}\text { number of } \\
\text { young bulls }\end{array}$ & $\begin{array}{c}\text { number of } \\
\text { daughters in } \\
\text { progeny test }\end{array}$ & $\begin{array}{c}\text { number of } \\
\text { tested bulls }\end{array}$ \\
\hline 1: & 132 & 180 & 24 \\
2: & 132 & 180 & 12 \\
3: & 238 & 100 & 24 \\
4: & 238 & 100 & 12 \\
$5:$ & 477 & 50 & 24 \\
\hline
\end{tabular}

Weights that were used in overall selection index. The variable factors were the same as in alternative 1 .

\begin{tabular}{lcc}
\hline & $\begin{array}{c}\text { milk } \\
\text { production: }\end{array}$ & fertility \\
\hline $6:$ & 1 & 0.1 \\
$7:$ & 1 & 0.2 \\
$8:$ & 1 & 0.3 \\
$9:$ & 1 & 1 \\
\hline
\end{tabular}

The model for two traits was then

$\left[\begin{array}{l}\mathrm{a}_{1 \mathrm{j}} \\ \mathrm{a}_{2 \mathrm{j}}\end{array}\right]=0.5\left[\begin{array}{l}\mathrm{a}_{\mathrm{S} 1}+\mathrm{a}_{\mathrm{D} 1} \\ \mathrm{a}_{\mathrm{S} 2}+\mathrm{a}_{\mathrm{D} 2}\end{array}\right]+\mathrm{L}\left[\begin{array}{l}\mathrm{x} \\ \mathrm{y}\end{array}\right]$

where $\mathrm{x}$ and $\mathrm{y}$ are normally distributed random numbers $\sim \mathrm{N}(0,1)$.

$\mathrm{V}\left[\begin{array}{l}\mathrm{m}_{1 \mathrm{j}} \\ \mathrm{m}_{2 \mathrm{j}}\end{array}\right]=0.5\left[\begin{array}{cc}\sigma_{\mathrm{A} 1}^{2} & \sigma_{\mathrm{A} 12} \\ \sigma_{\mathrm{A} 12} & \sigma_{\mathrm{A} 2}^{2}\end{array}\right]=\mathrm{LL}^{\prime}$,

where

$\sigma_{\mathrm{Ai}}^{2}$ is the additive variance of trait $\mathrm{i}$,

$\sigma_{\mathrm{Aij}}$ is the additive covariance between traits $\mathrm{i}$ and $\mathrm{j}$.

$\mathrm{L}$ is a lower triangular matrix from Cholesky decomposition of symmetric variance-covariance matrix $\mathrm{V}\left(\mathrm{m}_{\mathrm{ij}}\right)$. If $\mathrm{r}_{\mathrm{G}}=-0.20$ then

$L=\left[\begin{array}{cl}0.707 & 0 \\ -0.141 & 0.693\end{array}\right]$.

To minimize computing time no individual daughters were generated, instead the mean of a daughter group for a bull as a deviation from the population mean.

$\bar{y}_{i j}=0.5 \mathrm{a}_{\mathrm{ij}}+\overline{\mathrm{e}}_{\mathrm{ij}}$, where

$\bar{y}_{i j}$ is the mean of daughter group of bull $\mathrm{j}$ in trait i,

$a_{i j}$ is the additive genetic value of bull $j$, $\overline{\mathrm{e}}_{\mathrm{ij}}$ is the deviation of the daughter group mean from the bull's additive genetic value.

The model for two traits was

$$
\begin{aligned}
& {\left[\begin{array}{l}
\overline{\mathrm{y}}_{1 \mathrm{j}} \\
\overline{\mathrm{y}}_{2 \mathrm{j}}
\end{array}\right]=0.5\left[\begin{array}{l}
\mathrm{a}_{1 \mathrm{j}} \\
\mathrm{a}_{2 \mathrm{j}}
\end{array}\right]+\mathrm{T}\left[\begin{array}{l}
\mathrm{x} \\
\mathrm{z}
\end{array}\right]+\mathrm{R}\left[\begin{array}{l}
\mathrm{y} \\
\mathrm{w}
\end{array}\right] \text {, and }} \\
& \left.\left.\mathrm{V}\left[\begin{array}{c}
\overline{\mathrm{e}}_{1 \mathrm{j}} \\
\overline{\mathrm{e}}_{2 \mathrm{j}}
\end{array}\right]=\frac{3}{4 \mathrm{n}_{\mathrm{j}}}\left[\begin{array}{ll}
\sigma_{\mathrm{A} 1}^{2} & \sigma_{\mathrm{A} 12} \\
\sigma_{\mathrm{Al} 2} & \sigma_{\mathrm{A} 2}^{2}
\end{array}\right]+\frac{1}{\mathrm{n}_{\mathrm{j}}}\right]_{\sigma_{\mathrm{E} 1}^{2}}^{\sigma_{\mathrm{E} 2}^{2}}\right]=\mathrm{TT}^{\prime}+\mathrm{RR},
\end{aligned}
$$

where

$\mathrm{T}$ and $\mathrm{R}$ are lower triangular matrices defined as before,

$\mathrm{x}, \mathrm{y}, \mathrm{z}, \mathrm{w}$ are normally distributed random numbers $\sim \mathrm{N}(0,1)$,

$\sigma_{\mathrm{Ei}}^{2}$ is the residual variance of trait i,

$n_{j}$ is the number of daughters of bull $j$.

The environmental correlation was assumed to be zero. If $\mathrm{r}_{\mathrm{G}}=-0.20$ then

$$
\mathrm{T}=\frac{1}{\mathrm{n}_{\mathrm{j}}}\left[\begin{array}{cl}
0.866 & 0 \\
-0.173 & 0.849
\end{array}\right] \text {. }
$$

Bull's predicted breeding values for both traits were evaluated from the formula (RoBERTSON and RENDEL 1950)

$0.5 \hat{a}_{i j}=\frac{0.25 \mathrm{n}_{\mathrm{j}} \mathrm{h}_{\mathrm{i}}^{2}}{1+0.25\left(\mathrm{n}_{\mathrm{j}}-1\right) \mathrm{h}_{\mathrm{i}}^{2}} \overline{\mathrm{y}}_{\mathrm{ij}}$,

where

$\hat{a}_{i j}$ is the predicted breeding value of bull $\mathrm{j}$ in trait $\mathrm{i}$,

$h_{i}^{2}$ is the heritability of trait $\mathrm{i}$,

$\mathrm{n}_{\mathrm{j}}$ is the number of daughters of bull $\mathrm{j}$.

An overall index for bulls was calculated as the sum of these predicted breeding values by giving different weights for milk production and fertility at different alternatives (Table 2). 
Table 3. Expected genetic response in milk production at different alternatives.

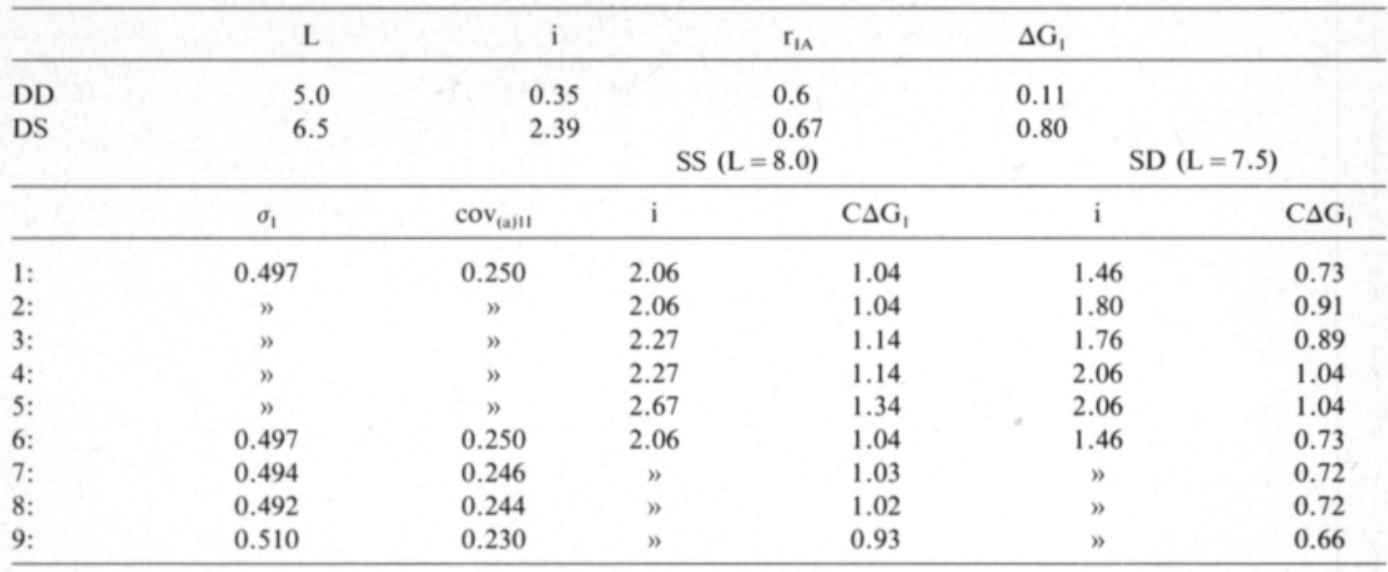

Expected genetic response/year in s.d. units. (Phenotypic s.d. $=800 \mathrm{~kg}$ ).

\begin{tabular}{ccccccccc}
\hline 1 & 2 & 3 & 4 & 5 & 6 & 7 & 8 & 9 \\
\hline 0.099 & 0.106 & 0.109 & 0.110 & 0.120 & 0.099 & 0.099 & 0.098 & 0.093 \\
\hline
\end{tabular}

In the alternatives from 1 to 5 the weights of milk production and fertility were 1 and 0.1 , respectively. Selection of tested bulls and bull sires was carried out on the basis of the overall index values.

The program was run in two stages. A starting program, the same for all alternatives, with 20 replicates was first run to get the breeding program into a stable stage. Variables in the starting program were the same as in the alternative 1 (Table 2). Thus all alternatives started from the same situation. A different number of young bulls was generated annually in different alternatives (Table 2). Tested bulls were used over three years for producing replacement cows. The effect of different alternatives were followed for 25 years and 20 replicates were run of each alternative.

\section{Results and discussion}

All the possible alternatives could not be run because of the computing time required. Alternatives were selected as extreme examples to show the change in the response with different breeding policies. The limiting factor is the number of tested bulls because we need

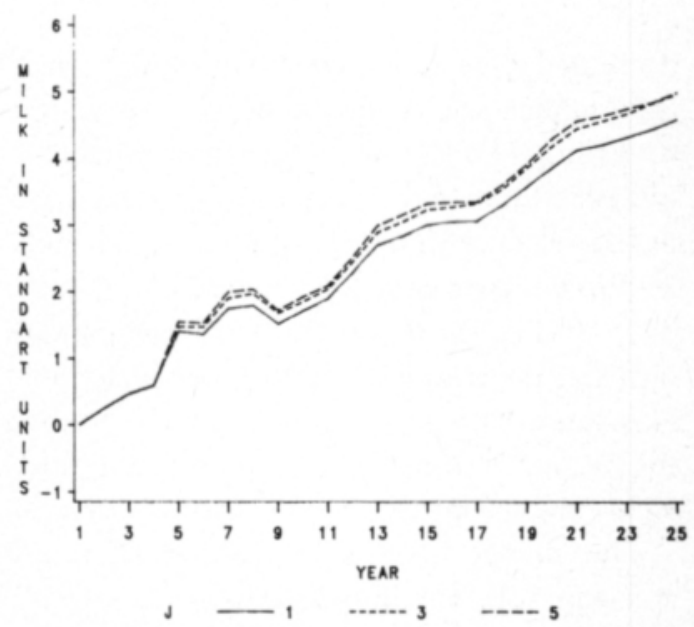

Fig. 1. The genetic response in milk production with different daughter group sizes in progeny test. The genetic s.d. is $400 \mathrm{~kg}$. See table 2 for more explanation.

a certain number of them to carry out all the inseminations in the population.

The Figures 1 and 2 show that by decreasing the number of daughters per bull in progeny test or in other words, testing more bulls per year, the genetic response in milk production could be improved. The improvement was obvious when the number of daughters 


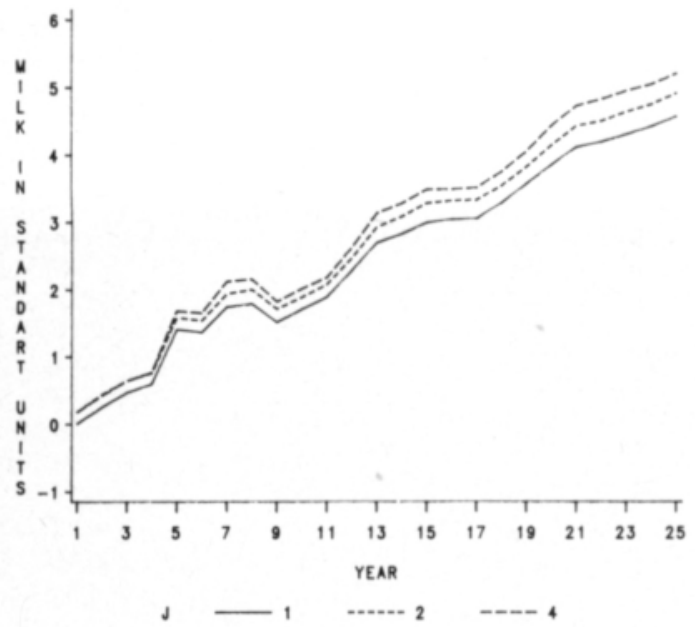

Fig. 2. The genetic response in milk production when the number of tested bulls selected per year and the number of daughters in progeny test varies. The genetic s.d. is $400 \mathrm{~kg}$. See Table 2 for more explanation.

decreased from 180 to 100 , but neligible when the number was further decreased from 100 to 50 (Fig. 1). The use of a smaller number of tested bulls in the program or the increase in the selection intensity among tested bulls lead to a higher genetic response in milk production (Fig. 2). Because of the large population size the standard error of the mean was very small, ca. $10 \mathrm{~kg}$, in all alternatives so that the estimates of the genetic response in milk yield can be considered as relatively accurate.

The change in milk production after increasing the weight of fertility in overall selection index is presented in Fig. 3. When milk production had a weight of 1 and the genetic correlation between traits was -0.20 , increasing the weight of fertility from 0.1 to 0.3 hardly decreased the genetic response of milk production. It had, however, a considerable effect on fertility (Fig. 4) so that the deterioration of fertility could be prohibited by putting more weight on it in the selection index. When both traits were given equal weight the fertility was even somewhat improved, but at the same time the response in milk yield clearly decreased (Figs. 3 and 4), even more than expected (Table 3 ).

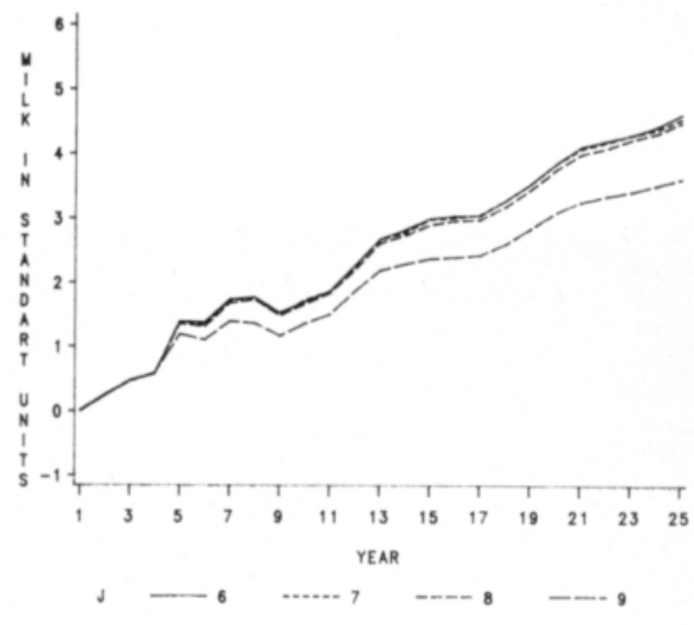

Fig. 3. The genetic response in milk production with different weights used in overall index. The genetic s.d. is $400 \mathrm{~kg}$.

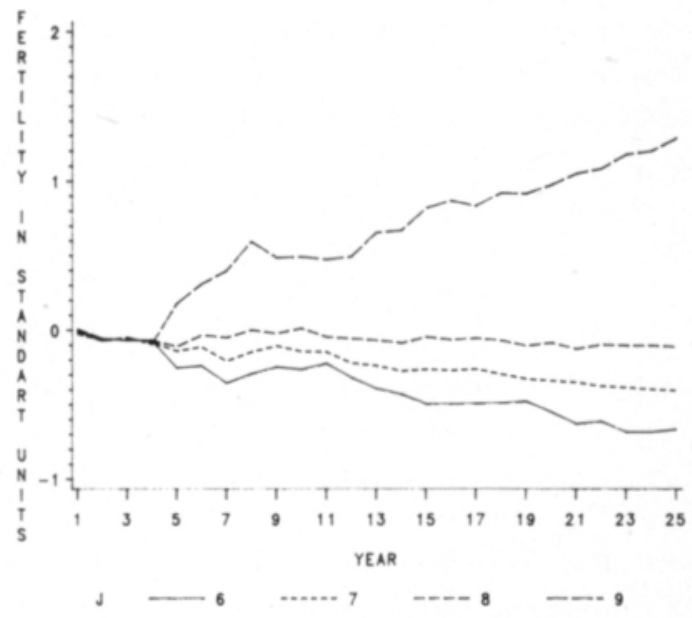

Fig. 4. The genetic change in fertility with different weights used in overall index. The genetic s.d. is 0.2 inseminations per pregnancy.

The results obtained from the simulation study were consistant with earlier studies and with the expected responses given in Table 3. The results indicate that the efficiency of the breeding program can be improved by more intensive selection of tested bulls and by testing more young bulls. By increasing the efficiency of progeny testing scheme the response in milk production can be improved 
without any major changes in the testing capacity, in other words with small investments. Also traits which have low heritability and which might be negatively correlated with milk production, such as fertility traits, some diseases etc., can be taken into account in breeding programs and some improvement can be expected by having appropriate weights

\section{References}

FALCONER, D.S. 1981. Introduction to Quantitative Genetics. 2nd edn., Longman, London.

HıL, W.G. 1974. Prediction and evaluation of response to selection with overlapping generations. Anim. Prod. 18: 117-139.

LINDHE, B. 1976. Model simulation of A.I.-breeding within a dual-purpose breed of cattle. Acta Agr. Scand. 18: $33-41$.

LINDSTRÖM, U.B. 1969. Genetic change in milk yield and fat percentage in artificially bred populations of Finnish dairy cattle. Acta Agr. Fenn. 114: 1-128.

LINDSTRÖ, U.B. and VILVA, V. 1976. Economic breeding for milk and beef in Finnish Ayrshire. Symp. on Ayrshire Cattle Breeding, Finland, 20th-25th September, 1976.

M.Clintock, A.E. and Cunningham, E. P. 1974. Selection in dual purpose cattle populations: Defining the breeding objective. Anim. Prod. 18: 237-247.

RENDEL, J.M. and Robertson, A. 1950. Estimation of genetic gain in milk yield by selection in a closed herd in the selection index. If traits of low heritability are included, the number of daughters per bull in progeny testing has to be kept large enough for the accurate evaluation on such traits.

Acknowledgements. The advice and comments of Dr. Asko Mäki-Tanila are greatly appreciated. of dairy cattle. J. Genetics 50: 1-8.

Robertson, A. and Rendel, J.M. 1950. The use of progeny testing with artificial insemination in dairy cattle. J. Genetics 50: 21-31.

SKJervold, H. 1963. The optimum sizè of progeny groups and optimum use of young bulls in AI breeding. Acta Agr. Scand. 13: 131-140.

SkJervold, H. and Langholz, H.J. 1964. Factors affecting the optimum structure of AI breeding in dairy cattle. Z. Tierz. Zücht. biol. 80: 25-40.

$V_{A N}$ V LECK, L.D. 1964. Sampling the young sire in artificial insemination. J. Dairy Sci. 47: 441-446.

VAN VLECK, L.D. 1981. Potential genetic impact of artificial insemination, sex selection, embryo transfer, cloning, and selfing in dairy cattle. In SEIDEL, G.F. and SEIDEl, G.F. Jr. (eds.) New Technologies in Animal Breeding 1981. Academic Press, Inc., New York. pp. $221-242$.

Ms received March 23, 1987

\section{SELOSTUS}

\section{Simulaatiotutkimus tarkoituksen- mukaisimmasta lypsykarjasonnien käytöstä jalostusohjelmissa}

\section{J. Juga}

Kotieläinjalostusosasto Maatalouden tutkimuskeskus 31600 Jokioinen

\section{J. Syväjärvi}

Suomen Kotieläinjalostusyhdistys PL 40 01301 Vantaa

\section{Vilva}

\section{Kotieläinten jalostustieteen laitos Helsingin yliopisto $00710 \mathrm{Helsinki}$}

Erilaisia lypsykarjan jalostusohjelmavaihtoehtoja tutkittiin tietokonesimulaatiolla. Tarkastellut ominaisuudet olivat maitotuotos ja sen kanssa negatiivisesti korreloitunut alhaisen periytyvyysasteen ominaisuus, esim. hedel- 
mällisyys. Valinnan tehoon vaikuttavina tekijöinä tutkittiin jälkelăisarvosteltavien nuorsonnien lukumääräă, sonnikohtaista tytärmäärää, valiosonnien määrää ja sonnien kokonaisjalostusarvoon kuuluvien ominaisuuksien painotusta.

Tekijöiden vaikutusta maitotuotoksessa ja hedelmällisyydessä saavutettuun perinnölliseen edistymiseen ilmaistiin laskemalla molemmille ominaisuuksille lehmien todellisten perinnöllisten arvojen vuosittaiset keskiarvot. Jalostusohjelmaa seurattiin 25 vuotta. Simulaatiossa käytetty populaatiorakenne pyrki jäljittelemään suomalais- ta ayrshirelehmien tarkkailupopulaatiota (noin 250000 lehmää).

Maitotuotoksen perinnöllinen edistyminen parani kun sonnien valintaintensiteettiä lisăttiin. Maitotuotoksen valinnasta johtunutta hedelmällisyyden huononemista voitiin hidastaa antamalla tälle ominaisuudelle suurempi paino kokonaisjalostusarvossa. Kun maitotuotoksella oli paino 1 ja ominaisuuksien välinen korrelaatio oli -0.20 , hedelmällisyyden painon kohottaminen 0.1 :stä 0.3 :een ei vaikuttanut merkittävästi maitotuotoksen jalostukselliseen paranemiseen. 